\title{
Influence of Personality Trait of Teachers Teaching Technical Drawing in Technical Colleges in Edo and Delta States
}

\author{
Patrick S. O. Uddin ${ }^{1}$, Samuel Chukwuemeka Nwachokor ${ }^{2}$ \\ ${ }^{1}$ Department of Vocational and Technical Education, Faculty of Education, Ambrose Alli University, Ekpoma, Nigeria \\ ${ }^{2}$ Department of Computer and Robotics Education, Faculty of Vocational and Technical Education, University of Nigeria, Nsukka, Nigeria
}

Email address:

uddinpatrick@gmail.com (P. S. O. Uddin), samchokor $a$ gmail.com (S. C. Nwachokor)

\section{To cite this article:}

Patrick S. O. Uddin, Samuel Chukwuemeka Nwachokor. Influence of Personality Trait of Teachers Teaching Technical Drawing in Technical Colleges in Edo and Delta States. Education Journal. Vol. 8, No. 3, 2019, pp. 120-124. doi: 10.11648/j.edu.20190803.15

Received: March 1, 2019; Accepted: May 23, 2019; Published: June 11, 2019

\begin{abstract}
This study examines the influence of personality trait of teachers teaching technical drawing in technical colleges in Edo and Delta States of Nigeria. The study employed survey research design, which made use of a structured questionnaire for data collection. The data collected was analyzed using mean of 2.50 to analyze the research questions and standard deviation was used to indicate how close the response of the respondent on the research questions are and t-test was used to test the hypothesis 0.05 level of significance. The findings of this study showed that teachers were not very effective, most of them have poor personality traits.
\end{abstract}

Keywords: Teacher Behaviour, Technical Drawing, Personality Traits, Pedagogical Profession

\section{Introduction}

Teaching is the act of helping others learn to do particular things [1]. Teaching is the intentional passing on of information from one who knows more to one who knows less [2]. Teaching is something that is mostly learned through experience [1]. [3] Define teaching as the work of helping people learn worthwhile things. Teaching as a deliberate activity can increase students' opportunity to develop robust skill in and knowledge of a subject matter. [4] Believes that a good teacher is both born and made.

A teacher is a person who helps others to acquire knowledge, skill or virtue. The teacher is an indispensable factor in the development of potentialities and abilities of a society's younger generation [5]. According to Afe [6] a teacher is one who is intellectually, socially and emotionally stable, who loves children and is positively disposed towards the profession, inspires good qualities in students and teachers effectively. Anderson [7] further sees a teacher as a person who achieved the goals that education aimed at achieving. Gurrey [8] Said at the end of my life as a teacher I am convinced that it is personality that counts always and all the time.
Personality is the dynamic organization within the individual psycho physical systems that determines his unique adjustment to his environment [9]. Personality traits of teachers have been an important area of investigation [10]. A personality trait is relatively stable characteristic that causes individuals to behave in certain ways. Thus, a teacher's classroom operation or performance could be significantly influenced by some personal traits. As posited by the study [11], teachers' personality traits are reflected not only in their classroom performance, especially in their selection of instructional activities, materials, strategies, and classroom management techniques but their interaction with students.

Moreover, the literature is replete with evidence of the effects of teacher personality on teacher-student interaction [10]. Recently, the notion of "rapport" has been used to explain the nature of effective teacher-student interaction. Establishing effective rapport enables students to operate at levels of cognitive and affective functioning that are higher compared to those they could otherwise achieve [12]. Effective rapport requires that teachers be friendly, respectful, connected with students, and trustworthy [13]. A few personality traits are reported to facilitate the 
establishment of rapport between teacher and student.

Technical drawing is a medium of communication among artists, technologist, engineers, architectures, technicians etc. and is widely used in many fields and professions [14]. In Nigerian educational system technical drawing is in practice as a subject/module at various levels such as post-primary schools and tertiary institutions. For this, there is the need for its effective teaching in our technical colleges because technical drawing is key in the scientific and technological development of any nation [15].

\subsection{Statement of Problem}

One of the factors that may impede the realization of the objective of vocational education in the teaching of technical drawing is teachers' personality. The teacher teaching effectiveness starts from his personality. There is a tremendous diversity in human nature, some people are friendly while others are hostile, some are quiet, other boisterous, some open-minded and tolerant while others are closed-minded and bigoted. Such characteristic inter-lock and make people unique individuals. Personality therefore, is all the relatively stable and administrative styles of thoughts, behaviour and emotional responses that characterize a persons' ability to adapt to prevailing circumstances.

\subsection{Research Question}

What is the influence of personality trait of teachers on the academic achievement of students in the teaching of Technical Drawing in Technical Colleges in Edo and Delta States?

\subsection{Hypothesis}

There is no significant difference in teachers' effectiveness between the good trait personality and push-over trait personality teachers in the teaching of Technical Drawing in technical colleges.

\section{Methodology}

Descriptive survey research design was adopted in carrying out this research. Descriptive survey is a study that entails the systematic collection of data to give a clear picture of a particular situation. The rationale is that the study aims at collecting data and examines the influence of the personality trait of teachers in the teaching of technical drawing in technical colleges in Edo and Delta States. The population of this study is made up of 35 Technical Drawing teachers and 816 final year students. Yaro Yamane was used for the sampling for the student population while total sampling was used for the teacher's population. The research instrument used in collecting the data is the questionnaire and it was titled Teachers' Personality Trait Questionnaire (TPTQ). The questionnaire consists of 18 questions based on the research questions drawn, Mean was used to determine the research questions, and standard deviation was used to point out the response of respondents from group mean, while t-test was used to test the level of significance of the null hypotheses at a level of 0.05 level of significance was used to determine if it will be accepted or rejected.

\section{Discussion of Findings and Conclusion}

Table 1. Mean and standard statistics of the influence of personality trait on teachers' effectiveness.

\begin{tabular}{|c|c|c|c|c|c|c|c|}
\hline \multirow{2}{*}{$\mathbf{S} / \mathbf{N}$} & \multirow{2}{*}{ Variable of Teachers' Effectiveness } & \multicolumn{3}{|c|}{ Good Trait n = 12} & \multicolumn{3}{|c|}{ Push-Over Trait $\mathbf{n}=\mathbf{2 3}$} \\
\hline & & $\mathbf{x}$ & SD & Remark & $\mathbf{X}$ & SD & Remark \\
\hline 1 & Uses of variety of instructional strategies & 2.40 & 0.49 & $\mathrm{NE}$ & 2.10 & 0.43 & $\mathrm{NE}$ \\
\hline 2 & Demonstrates patience, empathy and understanding & 2.20 & 0.45 & NE & 1.20 & 0.25 & $\mathrm{NE}$ \\
\hline 3 & Monitors students understanding and re-teaches & 4.00 & 0.82 & $\mathrm{E}$ & 2.50 & 0.52 & $\mathrm{E}$ \\
\hline 4 & Provides practice and reviews for students & 2.30 & 0.47 & $\mathrm{NE}$ & 2.04 & 0.42 & $\mathrm{NE}$ \\
\hline 5 & Creates positive classroom environment & 3.81 & 0.78 & $\mathrm{E}$ & 2.52 & 0.51 & $\mathrm{E}$ \\
\hline 6 & Assist students in discovering and correcting errors and inaccuracy & 2.05 & 0.42 & $\mathrm{NE}$ & 1.10 & 0.22 & $\mathrm{NE}$ \\
\hline 7 & Teacher stimulates students' interest & 4.00 & 0.82 & $\mathrm{E}$ & 2.60 & 0.53 & $\mathrm{E}$ \\
\hline 8 & Uses variety of sensory materials & 2.06 & 0.42 & $\mathrm{NE}$ & 1.50 & 0.31 & $\mathrm{NE}$ \\
\hline 9 & Uses variety of cognitive levels in strategies of questioning & 3.52 & 0.72 & $\mathrm{E}$ & 2.10 & 0.43 & $\mathrm{NE}$ \\
\hline 10 & Provides opportunities for successful experience by students & 3.50 & 0.72 & $\mathrm{E}$ & 2.50 & 0.51 & $\mathrm{E}$ \\
\hline 11 & Uses convergent and divergent inquiry strategies & 2.20 & 0.45 & $\mathrm{NE}$ & 2.10 & 0.43 & $\mathrm{NE}$ \\
\hline 12 & Demonstrates proper listening skills & 3.80 & 0.78 & $\mathrm{E}$ & 1.52 & 0.31 & $\mathrm{NE}$ \\
\hline 13 & Maintains an environment in which students are actively involved & 3.60 & 0.74 & $\mathrm{E}$ & 2.52 & 0.51 & $\mathrm{E}$ \\
\hline 14 & Encourages students to ask questions & 3.80 & 0.78 & $\mathrm{E}$ & 2.60 & 0.53 & $\mathrm{E}$ \\
\hline 15 & Provides positive feedback to students on their performance & 3.90 & 0.80 & $\mathrm{E}$ & 2.50 & 0.51 & $\mathrm{E}$ \\
\hline 16 & Develops and demonstrate problem-solving skill & 2.35 & 0.48 & $\mathrm{NE}$ & 2.25 & 0.46 & $\mathrm{NE}$ \\
\hline 17 & Gives clear directions and explanations & 2.35 & 0.48 & NE & 2.15 & 0.52 & $\mathrm{NE}$ \\
\hline \multirow[t]{2}{*}{18} & Implements an effective classroom management system for positive behaviour & 4.01 & 0.82 & $\mathrm{E}$ & 2.50 & 0.52 & $\mathrm{E}$ \\
\hline & Overall Mean & 3.10 & 0.64 & $\mathrm{E}$ & 2.13 & 0.44 & $\mathrm{NE}$ \\
\hline
\end{tabular}

Note: E - Effective.

$\mathrm{NE}$ - Not Effective.

Table 1 reveals the mean scores and the standard deviation of the influence of the good trait personality and the push- over trait personality Technical Drawing teachers on their effectiveness in the teaching of Technical Drawing. The 
Table shows that the good trait personality of Technical Drawing teachers had mean score above the 2.50 cut-off point in 10 variables of teachers' effectiveness out of the 18 variables of teachers' effectiveness and they had a mean score less than 2.50 cut-off point in eight variables of teachers' effectiveness, which shows that they were not effective in these eight variables of teachers' effectiveness. In the areas where the Technical Drawing teachers were effective in the variable of effectiveness, the mean score of the Technical Drawing teachers range from 3.5 to 4.00 while in the areas where the Technical Drawing teachers were not effective, the mean score in the variables of effectiveness of the teachers range from 2.05 to 2.40 .

The same Table indicates that the push-over trait personality Technical Drawing teachers had a mean score above the 2.50 cutoff point in eight variables of teachers' effectiveness out of the 18 variables of teachers' effectiveness and they had a mean score less than 2.50 cut-off point in 10 variables of teachers' effectiveness which shows that they were not effective in these 10 variables of teachers' effectiveness. In the areas where the Technical Drawing teachers were effective, the mean score of the variables of effectiveness of the push-over Technical Drawing teachers range from 2.50 to 2.60 while in the areas where the Technical Drawing teachers were not effective, the mean score of the variables of effectiveness of the teachers range from 1.10 to 2.25 . Table 1 further reveals that 12 out of the 35 Technical Drawing teachers had good trait personality while 23 Technical Drawing teachers had push-over trait personality. Also, the overall mean score 3.10 of the good trait personality Technical Drawing teachers is above the mean score of 2.50 cut-off point, an indication that they were effective. The overall mean score of 2.13 of the push-over trait personality Technical Drawing teachers is less than the 2.50 cutoff point, which shows that they were not effective. In addition, nine out of the 12 good trait personality Technical Drawing teachers were B. Sc. (Ed.) while three good trait personality Technical Drawing teachers were NCE (Tech.). Also, 16 out of the 23 push-over trait personality Technical Drawing teachers had B. Sc. (Ed.) while seven of the push-over trait personality Technical Drawing teachers had NCE (Tech.).

Table 2. Mean score of personality trait of technical drawing teachers' academic achievement of their students.

\begin{tabular}{llll}
\hline Group & Teachers & Students & X \\
\hline Good Trait & 12 & 300 & 56.45 \\
Push-Over Trait & 23 & 300 & 40.83 \\
\hline
\end{tabular}

Table 2 pointed out that students taught by the good trait personality Technical Drawing teachers have higher academic achievement with a mean score of 56.45 than those taught by push over trait personality Technical Drawing teachers with a mean score of 40.83 .

Table 3. T-test analysis of influence of attitude to work on teachers' effectiveness.

\begin{tabular}{|c|c|c|c|c|c|c|c|c|c|}
\hline $\mathbf{S} / \mathbf{N}$ & Variables of Teachers' Effectiveness & Attitude Variables & n & $\mathbf{x}$ & SD & df & t-Cal & t-Crit & Remarks \\
\hline \multirow{2}{*}{1} & \multirow{2}{*}{ Uses of variety of instructional strategies } & Positive & 12 & 3.20 & 0.65 & \multirow{2}{*}{33} & \multirow{2}{*}{5.00} & \multirow{2}{*}{1.96} & \multirow{2}{*}{$\mathrm{S}$} \\
\hline & & Negative & 23 & 2.50 & 0.51 & & & & \\
\hline 2 & Demonstrates patience, empathy and understanding & Positive & 12 & 2.41 & 0.49 & 33 & 1.75 & 1.96 & NS \\
\hline \multirow{2}{*}{3} & \multirow{2}{*}{ Monitors students understanding and re-teaches } & Positive & 12 & 3.72 & 0.80 & \multirow{2}{*}{33} & \multirow{2}{*}{7.00} & \multirow{2}{*}{1.96} & \multirow{2}{*}{$\mathrm{S}$} \\
\hline & & Negative & 23 & 2.61 & 0.53 & & & & \\
\hline 4 & Provides practice and reviews for students & Positive & 12 & 2.40 & 0.49 & 33 & 0.91 & 1.96 & $\mathrm{~S}$ \\
\hline \multirow[b]{2}{*}{5} & \multirow{2}{*}{ Creates positive classroom environment } & Positive & 12 & 4.01 & 0.82 & \multirow{2}{*}{33} & \multirow{2}{*}{5.65} & \multirow{2}{*}{1.96} & \\
\hline & & Negative & 23 & 3.05 & 0.62 & & & & $\mathrm{~S}$ \\
\hline 6 & Assist students in discovering and correcting errors & Positive & 12 & 2.42 & 0.49 & & 370 & & $\mathrm{~S}$ \\
\hline 0 & and inaccuracy & Negative & 23 & 2.05 & 0.41 & 33 & 3.10 & 1.96 & $\mathrm{~S}$ \\
\hline 7 & Teacher stimulates students' interest & Positive & 12 & 3.05 & 0.62 & 33 & 286 & 196 & $\mathrm{~S}$ \\
\hline 1 & 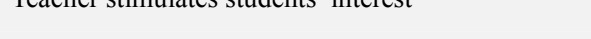 & Negative & 23 & 2.65 & 0.54 & JJ & 2.00 & 1.90 & $\mathrm{~S}$ \\
\hline 8 & & Positive & 12 & 2.05 & 0.41 & 33 & 1063 & & $\mathrm{~S}$ \\
\hline 8 & Uses variety or sensory materials & Negative & 23 & 1.20 & 0.25 & 33 & 10.03 & 1.90 & $\mathrm{~S}$ \\
\hline 9 & questioning & Negative & 23 & 2.60 & 0.53 & 53 & 4.29 & 1.90 & $\mathrm{~S}$ \\
\hline 10 & Provides opportunities for successful experience by & Positive & 12 & 3.50 & 0.72 & 33 & 1000 & 196 & $\mathrm{~S}$ \\
\hline 10 & students & Negative & 23 & 2.50 & 0.51 & 33 & 10.00 & 1.90 & $\mathbf{S}$ \\
\hline 11 & Uses conyeroent and diveroent inguiry strateoies & Positive & 12 & 2.20 & 0.45 & 33 & 190 & 196 & NS \\
\hline 11 & Uses convergent and aivergent mquiry strategies & Negative & 23 & 2.01 & 0.41 & 53 & 1.90 & 1.90 & NS \\
\hline 12 & Demonstrates proner listening skills & Positive & 12 & 3.90 & 0.80 & 33 & 8.13 & 196 & $\mathrm{~S}$ \\
\hline & & Negative & 23 & 2.60 & 0.53 & 33 & 8.13 & 1.90 & $\mathrm{~S}$ \\
\hline 13 & Maintains an environment in which students are & Positive & 12 & 2.94 & 0.60 & 33 & 323 & 196 & $\mathrm{~S}$ \\
\hline 15 & actively involved & Negative & 23 & 2.52 & 0.51 & 53 & 5.25 & 1.90 & $\mathbf{S}$ \\
\hline 14 & Encourages students to ask guestions & Positive & 12 & 3.80 & 0.78 & 33 & 750 & 196 & $\mathrm{~S}$ \\
\hline 14 & Encourages students to ask questions & Negative & 23 & 2.60 & 0.53 & 35 & 1.50 & 1.90 & $\mathrm{~S}$ \\
\hline 15 & Provides positive feedback to students on their & Positive & 12 & 2.80 & 0.57 & 33 & 3.08 & 1.96 & $\mathrm{~S}$ \\
\hline & performance & Negative & 23 & 2.40 & 0.49 & & & & $\mathrm{~S}$ \\
\hline
\end{tabular}

Note: $\mathrm{S}$ - Significan.

NS - Not Significant. 
Table 3 outlined the t-test analysis of the attitude to work on teachers' effectiveness between the positive attitude to work and the negative attitude to work Technical Drawing teachers in the teaching of Technical Drawing in technical colleges. The Table revealed that two out of 18 variables of teachers' effectiveness indicated a t-test calculated value less than the criterion value of 1.96. Since each of the variables of teachers' effectiveness has t-calculated value lower than the criterion value of 1.96 . Thus, the null hypothesis $\left(\mathrm{Ho}_{1}\right)$ is retained. Therefore, in those two variables of teachers' effectiveness there is no significant difference between the positive attitude to work and the negative attitude to work Technical Drawing teachers. In each of the other 16 variables of teachers' effectiveness, the t-test calculated value is greater than the criterion value of 1.96. Since each of the variables of teachers' effectiveness has t-test calculated value greater than the criterion value of 1.96 . Thus, the null hypothesis $\left(\mathrm{Ho}_{1}\right)$ is rejected. Therefore, there is a significant difference between the positive attitude to work and the negative attitude to work Technical Drawing teachers in the 16 variables of teachers' effectiveness in favour of the positive attitude to work. The results of this study also have revealed that the good trait personality Technical Drawing teachers were more effective than the push-over trait personality Technical Drawing teachers but less in number, only 12 out of the 35 Technical Drawing teachers. The behaviour of the students is often the major concern of all, such that the personality behaviours of the teachers are often overlooked. The teacher spends most of the school day in close association with his/her students and as a result, his/her basic attitude and actions, tastes and mannerisms have great influence on the students. This directly affects the students because they learn attitude and behaviour by examples. [16] Further stressed that emotional tensions are contagious. For instance, a teacher who is fearful, tense and generally hostile can induce fear, and insecurity in his/her students. The learning situation is also affected by the personality and behaviour of the teacher since students' response to what is being taught is determined largely by their responses to the teacher. A teacher must strive to interest students in the subject he/she teaches. Effective or ineffective teachers with corresponding good or poor personality often determine not only the response to their own course but also the students' future attitude towards the entire subject. When adults for instance are asked to recall which resource they like and disliked while in school, the popular course were taught by the teachers who were best informed and most stimulating. Some teachers display a push-over trait, of just teaching the students without showing much concern about the student's behaviour. This type of trait is linked with prior experiences involving situational pressures in the family setting in combination with social and biological pressures [17]. The findings of this study showed that teachers were not very effective, most of them have poor personality traits, the study also shows that most teachers lack patience, empathy and understanding, the study also shows that teachers are not effective in demonstrating skills to solve problems, teachers are not effective in giving clear direction and explanation to students.

\section{Conclusion}

Teaching of technical drawing will aid students in various technical courses, but the teacher must have a good personality trait otherwise the teacher would not be effective in teaching of technical education.

\section{References}

[1] Deborah, L. B. and Francesca M. F. (2009). The work of teaching and the challenge for teacher education. Journal of Teacher Education, 60 (5), 497 -511.

[2] Pillemer, D. and White, S. (2005) Developmental psychology and social change, Eds. New York: Cambridge University Press, pp. 368-388.

[3] Feiman-Nemser, S. and Buchmann, M. (1986). The first year of teacher preparation: Transition to pedagogical thinking. Journal of Curriculum Studies, 18, 239-256.

[4] Banjo, S. A. (2003) A West Africa teacher's handbook. London: Hodder and Stoughton.

[5] Utulu, C. C. (2003). Factors of teacher satisfaction and dissatisfaction in teaching. Journal of Nigeria Education Research Association (16 and 17), 1-13.

[6] Afe, J. O. (2003). Teachers' effectiveness: Imperative for implementing Universal Basic Education (U. B. E). Journal of the Nigeria Academy of Education, 1 (1), 1-9.

[7] Anderson, L. W (1991). Increasing teacher effectiveness: Paris UNESCO. International Institute for Education Planning Journal, 1 (1), 1-9.

[8] Gurrey, P. (1993). Education and the training of teacher. London: Longman Groups.

[9] Allport, G. W. (1965). Patterns and growth in personality. New York: Holt, Rinehart and Winton, Inc.

[10] Gao, M. \& Liu, Q. (2013). Personality traits of effective teachers represented in the narratives of American and Chinese teachers: A cross-cultural comparison. International Journal of Humanities and Social Science, 3 (2), 84-95.

[11] Henson, R., \& Chambers, S. (2002). Personality types as a predictor of teaching efficacy and classroom control beliefs in emergency certification teachers. Paper presented at the Annual Meeting of the Southwest Educational Research Association, Feb. 14-16, Austin, TX.

[12] Wray, D., Medwell, J., Fox, R., \& Poulson, L. (2000). The teaching practices of effective teachers of literacy. Educational Review, 52 (1), 75-84.

[13] Zhang, L. F. (2004). Thinking styles: University students' preferred teaching styles and their conceptions of effective teachers. The Journal of Psychology, 138 (3), 233-252. 
[14] Chedi, J. M. (2015). Technical drawing/graphic skills acquisition for teaching, learning and challenges in technology education. ATBU, Journal of Science, Technology \& Education, 3 (3), 128-133.

[15] Elom, E. N. (2014). Effective teaching and learning in technical colleges: Challenges of technical drawing. Journal of Education Policy and Entrepreneurial Research, 1 (1), 7686.
[16] Sorenson, H. (1994). Psychology in education. University of Kentucky: New York: McGraw-Hill Book Company.

[17] Afe, J. O. \& Alutu, A. N. G. (2002). Developmental psychology. Benin City: Stirling Hordan Publishers (Nig.) Ltd. 